\title{
Late summer phytoplankton distribution along a 3500 km transect in Canadian Arctic waters: strong numerical dominance by picoeukaryotes
}

\author{
Geneviève Tremblay ${ }^{1}$, Claude Belzile ${ }^{1}$, Michel Gosselin ${ }^{1, *}$, Michel Poulin ${ }^{2}$, \\ Suzanne Roy ${ }^{1}$, Jean-Éric Tremblay ${ }^{3}$ \\ ${ }^{1}$ Institut des sciences de la mer de Rimouski, Université du Québec à Rimouski, 310 Allée des Ursulines, Rimouski, \\ Québec G5L 3A1, Canada \\ ${ }^{2}$ Research Division, Canadian Museum of Nature, PO Box 3443, Station D, Ottawa, Ontario K1P 6P4, Canada \\ ${ }^{3}$ Québec-Océan, Département de biologie, Pavillon Alexandre-Vachon, Université Laval, Québec, Québec G1V OA6, Canada
}

\begin{abstract}
A number of recent studies showed that photosynthetic picoeukaryotes are an active and often dominant component of Arctic algal assemblages. In order to place these observations in a large-scale context, samples were collected in the euphotic zone along a $3500 \mathrm{~km}$ transect across northern Baffin Bay, the Northwest Passage and the Beaufort Sea during late summer 2005. Picophytoplankton $(<2 \mu \mathrm{m})$ and nanophytoplankton cells $(2$ to $20 \mu \mathrm{m}$ ) were enumerated using flow cytometry, and phytoplankton cells $>2 \mu \mathrm{m}$ were identified and counted by light microscopy. Pigment composition of the total community was assessed by reverse-phase HPLC to determine the relative contribution of different algal groups. The spatial distribution of phytoplankton was heterogeneous along the transect. The highest abundance of picophytoplankton was observed in the Beaufort Sea/Northwest Passage region, whereas nanophytoplankton increased numerically toward the eastern Canadian Arctic. Picophytoplankton abundance reached a maximum of $18400 \mathrm{cells} \mathrm{ml}^{-1}$ and accounted for $>70 \%$ of total cell counts in two-thirds of the samples. The $<2 \mu \mathrm{m}$ size fraction held a similar share of total $\mathrm{chl} a$, which reached a maximum of $6 \mu \mathrm{g} \mathrm{l^{-1 }}$. Overall, the picophytoplankton community was strongly dominated by eukaryotes (presumably the Prasinophyceae Micromonas). Maximum abundances of picocyanobacteria $\left(120 \mathrm{cells} \mathrm{m}^{-1}\right)$ were observed in brackish waters of the Beaufort Sea. These results confirm that picophytoplankton can dominate not only in warm oligotrophic waters, but also in a perennially cold ocean during late summer.
\end{abstract}

KEY WORDS: Abundance · Photosynthetic eukaryotes ' Picophytoplankton • Biomass · Nanophytoplankton · Microphytoplankton · Canadian Arctic

Resale or republication not permitted without written consent of the publisher

\section{INTRODUCTION}

The size distribution of phytoplankton assemblages has a major influence on the function of the pelagic food web and, consequently, affects the rate of carbon export from the open ocean surface waters to the deep layers (Legendre \& Le Fèvre 1991). Large rapidly sinking phytoplankton cells such as diatoms are believed to mediate the carbon flux from the upper ocean layers (Michaels \& Silver 1988) and to efficiently transfer energy to the upper trophic levels
(Cushing 1989). Large diatoms are at the base of herbivorous food webs, supporting renewable marine resources such as herbivorous zooplankton and fish (Cushing 1989). In contrast, small phototrophic picoplankton (cells from 0.2 to $2 \mu \mathrm{m}$; Sieburth et al. 1978) are believed to be recycled within the microbial food web (Azam et al. 1983), contributing less efficiently to the transfer of energy and matter to the upper trophic levels. Picophytoplankton cells are also considered to contribute less to the sinking material because of their low sinking fluxes (Michaels \& Silver 
1988). However, Richardson \& Jackson (2007) challenged this view by showing that the share of picophytoplankton in carbon export can match their relative contribution to total net primary production due to the inclusion of small cells into large aggregates that sink rapidly or are grazed by mesozooplankton. Considering the findings of Richardson \& Jackson (2007), the conventional view that picophytoplankton contribute little to carbon export should be revisited. Hence, both large and small phytoplankton play a crucial role in the marine biogeochemical cycle.

Large phytoplankton cells, including diatoms, prymnesiophytes and dinoflagellates, produce seasonal blooms under specific hydrographic conditions (Mei et al. 2002). For instance, the production of large phytoplankton is governed by variations in the vertical stability of the water column, through its effects on nutrient replenishment and the residence time of algal cells in the euphotic zone (e.g. Tremblay et al. 1997). In addition, the duration of the production period is sensitive to the seasonal melt dynamics of sea ice (Fortier et al. 2002). In northern Baffin Bay (BB), an intense diatom bloom characterized by cells $>5 \mu \mathrm{m}$ begins as early as the end of April when the North Water polynya opens up (Mei et al. 2002). In the Canadian Archipelago, particularly in Barrow Strait, the phytoplankton bloom typically develops in July and August, corresponding to the timing of the ice break-up for this region (Michel et al. 2006). In the Chukchi and Beaufort seas, high chlorophyll concentrations are observed in regions along the ice edge and are associated with an overwhelming predominance of diatoms and prymnesiophytes (Hill et al. 2005). In the Barents Sea, largecelled phytoplankton dominate during blooms at the marginal ice zone and are of particular importance for the production of organic matter and the vertical export of carbon (Wassmann et al. 2006).

Several studies have shown that small phytoplankton cells $(<5 \mu \mathrm{m})$ can also play an important role in carbon fixation in the Arctic Ocean and adjacent seas (Legendre et al. 1993, Gosselin et al. 1997). Picophytoplankton contribute most of the production and biomass in warm and nutrient-poor waters (Agawin et al. 2000). Recent studies have shown that picophytoplankton are often well represented numerically in cold Arctic seawaters. Indeed, eukaryotic cells $<2 \mu \mathrm{m}$ often dominate the phytoplankton assemblage, reach-

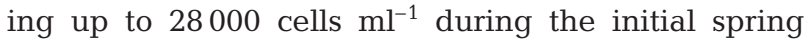
bloom in the central Arctic Ocean but usually ranging between 1000 and 10000 cells ml $^{-1}$ during the rest of the growth season (Sherr et al. 2003) and in summer (Booth \& Horner 1997), while Not et al. (2005) recorded abundances of 2600 to 10200 cells ml $^{-1}$ in Arctic waters of the Barents Sea in late summer. Within these small eukaryotic cells, Not et al. (2005) showed that the prasinophyte Micromonas pusilla (Butcher) Manton et Parke made up $32 \%$ of total picoeukaryotic cells at stations located in truly Arctic waters, but only $9 \%$ at stations influenced predominantly by Atlantic waters. In addition, Lovejoy et al. (2007) recently demonstrated that picoprasinophytes are spatially and temporally prevalent throughout the Arctic region where $M$. pusilla is the most abundant picoeukaryote representing a single high-latitude ecotype.

Picocyanobacteria are generally poorly represented in the Arctic seas (Murphy \& Haugen 1985, Booth \& Horner 1997, Mostajir et al. 2001, Sherr et al. 2003), in strong contrast with their high abundance in Arctic lakes and rivers (Vincent 2000). In the Southern Ocean, picocyanobacteria abundance decreases with increasing latitude, i.e. with decreasing temperature (Marchant et al. 1987). In the Arctic Ocean and adjacent seas, the 2 main sources of picocyanobacteria are Atlantic waters and freshwater river input. Not et al. (2005) have shown high abundances of the picocyanobacteria Synechococcus Nägeli in the Atlanticinfluenced waters of the Barents Sea, which are characterized by high surface water temperature. This corroborates earlier studies that identified cyanobacteria as bioindicators for the advection of Atlantic-influenced waters into the Arctic seas (Murphy \& Haugen 1985, Gradinger \& Lenz 1995). In the Laptev Sea, Moreira-Turcq \& Martin (1998) observed maximum picocyanobacteria concentrations in brackish water near the Lena River delta, but their absence at salinities $>20$. More recently, Waleron et al. (2007) suggested from 16S rRNA gene clone libraries that picocyanobacteria present in the Canadian Beaufort Sea originated from the Mackenzie River and other nearby inflows.

The cell size of phytoplankton taxa present in the ocean is, in part, determined by environmental and physiological factors. Given the transition toward a new, warmer state, it is expected that the relative abundance of picophytoplankton versus larger phytoplankton will change in Arctic regions. The objectives of the present study were to (1) determine the distribution of pico-, nano- and microphytoplankton in 3 contrasted oceanographic provinces of the Canadian High Arctic, and (2) assess the influence of environmental factors on the phytoplankton abundance and biomass of each size fraction. Our working hypothesis was that picocyanobacteria would be present in Atlantic-influenced waters and nearby river inflows, whereas the abundance of photosynthetic picoeukaryotes was expected to be higher in warm, stratified waters than in cold, deeply mixed waters. In agreement with comprehensive reviews of the available literature (Agawin et al. 2000, Bell \& Kalff 2001), the large phytoplankton $(>2 \mu \mathrm{m})$ were expected to be more abundant in nutrient-rich than in nutrient-poor waters. 


\section{MATERIALS AND METHODS}

Study sites and sampling. This study was conducted in the Canadian High Arctic from 16 August to 13 September 2005, hereafter referred to as late summer, over a $3500 \mathrm{~km}$ longitudinal transect, as part of the ArcticNet research program on board the CCGS 'Amundsen'. A total of 18 stations were visited consisting of 5 stations in northern BB (Stns BA01 to BA04 and 2), 5 stations in the Northwest Passage (NWP: Stns 3, 4, p, 6 and 7) and 8 stations in the Beaufort Sea (Stns 10 to 12, 204, CA04, CA05, CA08 and CA18) (Fig. 1). Water samples were collected at 3 depths (50 and $15 \%$ of surface irradiance and at the maximum chl a fluorescence depth) with a rosette sampler equipped with 12 l Niskin-type bottles (OceanTest Equipment), an in situ fluorometer (SeaPoint) and a high-precision Sea-Bird 911plus CTD probe. Since the depth of the maximum chl a fluorescence was generally located between 0.2 and $5 \%$ of surface irradiance, the 3 sampling depths are hereafter referred to as surface, intermediary and bottom layers of the euphotic zone, respectively.

Physical and chemical measurements. Incident photosynthetically active radiation $\left(E_{\mathrm{d}}(\mathrm{PAR}) ; 400\right.$ to $700 \mathrm{~nm}$ ) was measured continuously during the expedition with a LI-COR sensor (LI-190SA). Downwelling PAR underwater profiles were measured using a light sensor (QCP-2300, Biospherical Instruments) mounted on the CTD rosette, except at Stns 3, 7 and 11, where a
PNF-300 radiometer (Biospherical Instruments) was used. The vertical attenuation coefficient for downward PAR $\left(K_{\mathrm{d}}(\mathrm{PAR})\right)$ in the euphotic zone was determined by linear regression of the natural logarithm of $E_{\mathrm{d}}(\mathrm{PAR})$ versus depth. The euphotic depth $\left(Z_{\text {eu }}\right)$ was defined as the depth receiving $0.2 \%$ of the surface PAR. The surface mixed-layer depth $\left(Z_{\mathrm{m}}\right)$ was determined using a split-and-merge method (Thomson \& Fine 2003). $Z_{\mathrm{m}}$ was also defined as the depth where the vertical gradient in sigma-t is $>0.03 \mathrm{~m}^{-3}$. There was a strong linear relationship between the $Z_{\mathrm{m}}$ values determined from the $0.03 \mathrm{~m}^{-1}$ criterion $(y)$ and the Thomson \& Fine method $(x)(y=0.98 x-0.10 ; 95 \%$ CI from 0.82 to $\left.1.14, \mathrm{r}^{2}=0.91, \mathrm{p}<0.0001\right)$. An index of the vertical stratification of the water column was estimated as the difference in the sigma-t between 80 and $5 \mathrm{~m}$. The presence of ice was estimated visually at each station. Samples for nutrient determination were processed immediately after sampling on board the ship. Nitrate $\left(\mathrm{NO}_{3}\right)$, nitrite $\left(\mathrm{NO}_{2}\right)$, silicic acid $\left(\mathrm{Si}(\mathrm{OH})_{4}\right)$ and phosphate $\left(\mathrm{PO}_{4}\right)$ were analyzed using a Bran-Luebbe III autoanalyzer (adapted from Grasshoff et al. 1999), whereas ammonium $\left(\mathrm{NH}_{4}\right)$ was analyzed manually using the fluorometric method of Holmes et al. (1999).

Flow cytometry (FCM) analysis. Duplicate water samples $(5 \mathrm{ml})$ for the determination of pico- and nanophytoplankton abundance were fixed with $0.1 \%$ final concentration glutaraldehyde (Marie et al. 2005), stored in liquid nitrogen on board the ship and kept

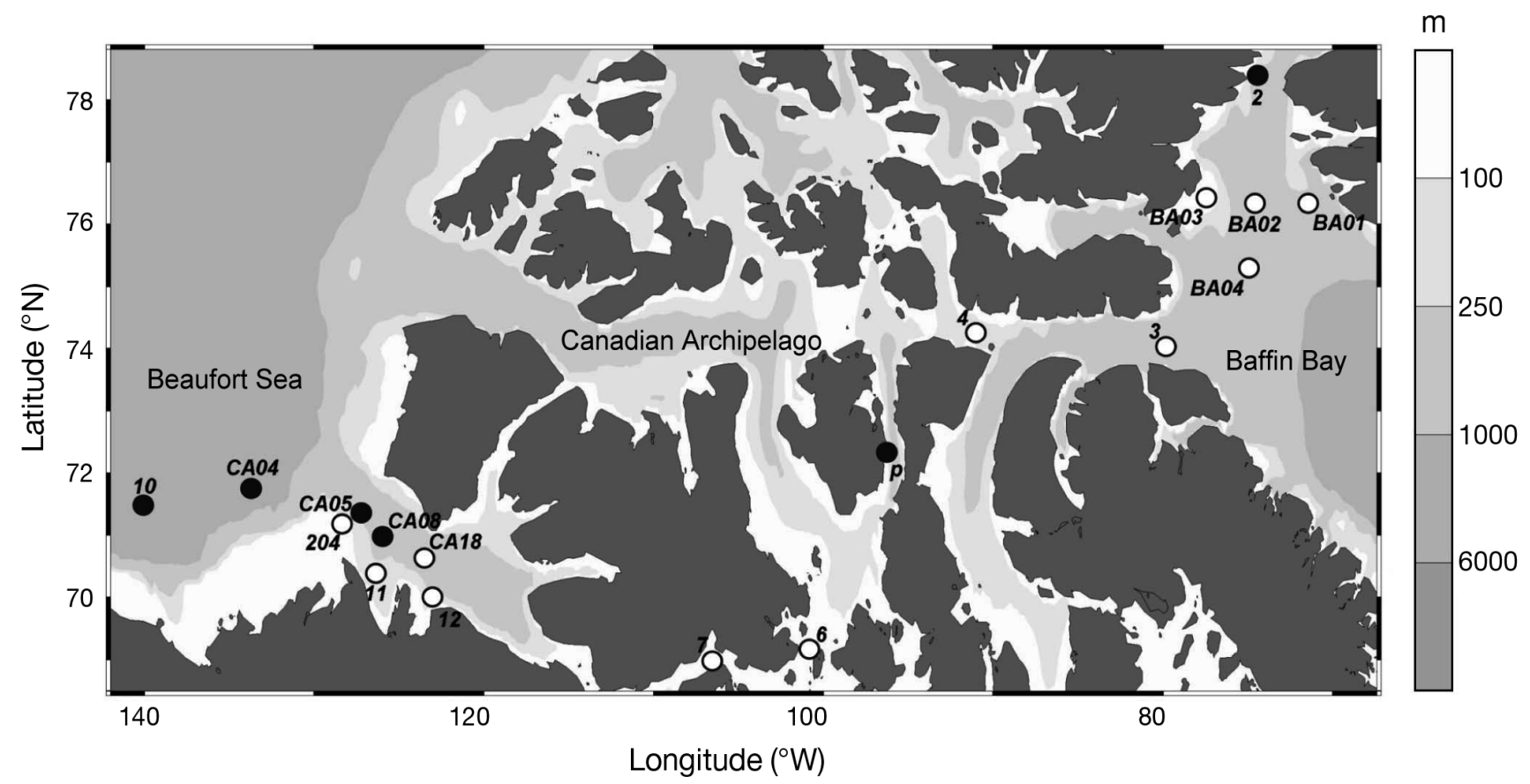

Fig. 1. Location of the sampling stations in the Canadian High Arctic visited from 16 August to 13 September 2005. O: open water; -: ice-covered conditions. Three oceanographic provinces were identified: Beaufort Sea (Stns 10, 11, 12, 204, CA04, CA05, CA08 and CA18), Northwest Passage in the Canadian Archipelago (Stns 3, 4, p, 6 and 7) and northern Baffin Bay (Stns BA01 to BA04 and 2) 
frozen at $-80^{\circ} \mathrm{C}$ for $1 \mathrm{wk}$ before analysis. Samples were analyzed using an EPICS ALTRA flow cytometer (Beckman Coulter) equipped with a $488 \mathrm{~nm}$ laser (15 mW output). Forward angle light scatter, right angle light scatter, orange fluorescence from phycoerythrin (575 $\pm 20 \mathrm{~nm})$ and red fluorescence from chlorophyll $(675 \pm 10 \mathrm{~nm})$ were measured. Prior to analysis, samples were pre-screened on a $40 \mu \mathrm{m}$ nylon cell strainer. Microspheres $(1 \mu \mathrm{m}$, Fluoresbrite plain YG, Polysciences) were added to each sample as an internal standard. Pico- $(<2 \mu \mathrm{m})$ and nanophytoplankton $(2$ to $20 \mu \mathrm{m})$ were discriminated based on forward scatter calibration with polystyrene microspheres of known size. With the flow cytometer configuration used in the present study, phycoerythrin-containing cyanobacteria were assessed as picocyanobacteria, whereas phycocyanin-containing cyanobacteria, if present, were counted with the eukaryotic picophytoplankton. The average coefficients of variation on the duplicate samples were 5.7 and $12.5 \%$ for pico- and nanophytoplankton abundances, respectively. The average of the 2 duplicates is presented hereafter.

Light microscopy (LM) analysis. Samples for the identification and enumeration of eukaryotic cells $>2 \mu \mathrm{m}$ were collected at 2 depths (the surface and at the bottom layers of the euphotic zone). They were preserved in acidic Lugol's solution (Parsons et al. 1984) and stored in the dark at $4^{\circ} \mathrm{C}$ until analysis. Samples were identified to the lowest possible taxonomic rank using an inverted microscope (Wild Heerbrugg) according to Lund et al. (1958). For each sample, at least 300 cells were counted. The main taxonomic references used to identify the phytoplankton were Tomas (1997) and Bérard-Therriault et al. (1999). For comparison with the FCM counts, autotrophic cells enumerated by microscopy were subdivided into the $<20 \mu \mathrm{m}$ (nanophytoplankton) and > $20 \mu \mathrm{m}$ (microphytoplankton) size classes. In the case of chain-forming diatoms, the size of the individual cells was considered as the criterion.

Pigment analysis. Water samples (2.5 to $3.5 \mathrm{l}$ ) for the identification of the phytoplankton pigment signature, collected in the surface layer, were filtered onto Whatman GF/F filters that were immediately frozen in liquid nitrogen on board the ship and stored at $-80^{\circ} \mathrm{C}$ prior to analysis. Algal pigments were extracted in $95 \%$ methanol $(\mathrm{MeOH})$, sonicated for a few seconds and centrifuged for $5 \mathrm{~min}$ at $3700 \times g$. Pigment extracts were then filtered onto $0.2 \mu \mathrm{m}$ polytetrafluoroethylene Gellman Acrodisc filters into amber glass vials and stored under argon gas at $4^{\circ} \mathrm{C}$ in darkness until measurement by reverse-phase HPLC within $24 \mathrm{~h}$ of extraction. The pigment extract was analyzed following Zapata et al. (2000) using eluant solution A (MeOH:acetonitrile:aqueous pyridine, 50:25:25, v:v), solution B (MeOH:acetonitrile:acetone, 20:60:20, v:v) and solution $\mathrm{C}$ (acetonitrile) at a flow rate of $1 \mathrm{ml} \mathrm{min}^{-1}$. The HPLC system consisted of a ThermoSeparation Products (TSP) P4000 pump, an AS-3000 autoanalyzer, a Waters Symmetry $C_{8}$ column $(4.6 \times 150 \mathrm{~mm}, 3.5 \mu \mathrm{m}$ particle size) and 2 detectors in series: a TSP UV 6000 LP absorbance detector (400 to $700 \mathrm{~nm}$ ) and a TSP FL3000 fluorescence detector. Absorbance chromatograms were obtained at $412 \mathrm{~nm}$ (for chlorophylls) and $450 \mathrm{~nm}$ (for carotenoids). Calibration was done with external standards obtained commercially from DHI Water \& Environment (Denmark) and extinction coefficients were taken from Jeffrey et al. (1997). Marker pigments were identified through comparison with the retention and spectral properties of standards. Phytoplankton taxonomic groups with their identifying pigments are listed in Table 1.

Size-fractionated biomass. Subsamples for the determination of chl $a$ in size fractions were filtered onto Whatman GF/F glass-fiber filters (nominal pore size of $0.7 \mu \mathrm{m}$ ) and onto $5 \mu \mathrm{m}$ Nuclepore polycarbonate membranes. Following an $18 \mathrm{~h}$ extraction in $90 \%$ acetone at $4^{\circ} \mathrm{C}$ in the dark without grinding, chl a concentrations were determined on a 10-005R Turner Designs fluorometer (Parsons et al. 1984). Chl a concentration of small phytoplankton ( 0.7 to $5 \mu \mathrm{m}$ ) was obtained by subtracting the chl a concentration of large phytoplankton from the total chl a concentration. The contribution of cells $<2 \mu \mathrm{m}$ to total chl a was estimated by multiplying the picophytoplankton abundance by a value of $0.025 \mathrm{pg}$ chl a per cell. This chl a cellular quota, also used by Not et al. 2005, is representative of the picoeukaryote Micromonas pusilla (DuRand et al. 2002), a common species in the Arctic (Lovejoy et al. 2007).

Statistical analyses. Before undertaking the different parametric tests, the normality of distribution and the homogeneity of variance of each variable were tested with the Lilliefors and the Levine tests, respectively. When required, data were log-transformed. For each variable, 1-way ANOVA was performed to look for any significant differences between the 3 oceanographic provinces (i.e. northern BB, NWP and Beaufort Sea). The ANOVA was completed by a multiple comparison test of means (Tukey's HSD test for unequal sample sizes; Sokal \& Rohlf 1995). When assumptions were not met, the Kruskal-Wallis test was used instead of the ANOVA. Simple linear (model I) and reduced major axis regressions (model II) were used to determine the relationship between 2 variables; the latter takes into account measurement errors for both dependent and independent variables (Sokal \& Rohlf 1995). When the relationship between 2 variables was monotonic, Spearman's rank correlation $\left(\mathrm{r}_{\mathrm{S}}\right)$ was computed (Sokal \& Rohlf 1995). Statistical analyses were carried out using SYSTAT version 10.2. 
Table 1. Distribution of major taxonomically significant pigments in algal classes using Scientific Committee on Oceanic Research abbreviations (Jeffrey et al. 1997). DVP: divinyl pheoporphyrin a5 monoethyl ester

\begin{tabular}{|c|c|c|}
\hline Pigment & Abbreviation & Specificity \\
\hline \multicolumn{3}{|l|}{ Chlorophylls } \\
\hline Chlorophyll $b$ & Chl $b$ & Chlorophytes, prasinophytes, euglenophytes \\
\hline Chlorophyll $c_{3}$ & $\mathrm{Chl} C_{3}$ & Prymnesiophytes, several diatoms and dinoflagellates \\
\hline Chlorophyll $C_{2}+C_{1}$ & $\mathrm{Chl} C_{2+} C_{1}$ & Most diatoms, dinoflagellates, cryptophytes, prymnesiophytes, chrysophytes \\
\hline $\mathrm{Mg}-2,4-\mathrm{DVP}$ & Mg DVP & Some prasinophytes \\
\hline \multicolumn{3}{|l|}{ Carotenoids } \\
\hline Alloxanthin & Allo & Cryptophytes \\
\hline 19'-butanoyloxyfucoxanthin & But-fuco & Prymnesiophytes, chrysophytes \\
\hline$\beta, \beta$-Carotene & $\beta \beta$-Car & All algae except cryptophytes and rhodophytes \\
\hline Diadinoxanthin & Diadino & Diatoms, dinoflagellates, prymnesiophytes, chrysophytes \\
\hline Diatoxanthin & Diato & Diatoms, dinoflagellates, prymnesiophytes, chrysophytes \\
\hline Fucoxathin & Fuco & Diatoms, prymnesiophytes, chrysophytes, raphidophytes, some dinoflagellates \\
\hline 19'-hexanoyloxyfucoxanthin & Hex-fuco & Prymnesiophytes \\
\hline Lutein & Lut & Chlorophytes, prasinophytes \\
\hline Micromonal & Mmnal & Chlorophytes, prasinophytes \\
\hline $9^{\prime}$-cis Neoxanthin & Neo & Chlorophytes, prasinophytes, euglenophytes \\
\hline Peridinin & Perid & Dinoflagellates \\
\hline Prasinoxanthin & Pras & Prasinophytes \\
\hline Uriolide & Uriolide & Chlorophytes, prasinophytes \\
\hline Violaxanthin & Viola & Chlorophytes, prasinophytes, eustigmatophytes \\
\hline Zeaxanthin & Zea & Cyanobacteria, prochlorophytes, chlorophytes \\
\hline \multicolumn{3}{|c|}{ Chlorophyll degradation products } \\
\hline Chlorophyllide a & Chlide $a$ & Senescent diatoms; extraction artifact \\
\hline Pheophorbide $a$ & Phide $a$ & Protozoan fecal pellets \\
\hline Pyropheophorbide $a$ & Pyro-Pheo & Copepod grazing; fecal pellets \\
\hline
\end{tabular}

\section{RESULTS}

\section{Physical and chemical environment}

Stations sampled along the $3500 \mathrm{~km}$ transect across the Canadian Arctic in late summer encompassed 3 distinct oceanographic provinces: northern BB, NWP and the Beaufort Sea. Physical and chemical variables measured in these provinces showed a large spatial variability. During the expedition, incident irradiance ranged from 8.2 to $24.7 \mathrm{~mol}$ photons $\mathrm{m}^{-2} \mathrm{~d}^{-1}$ with an average of $16.2 \mathrm{~mol}$ photons $\mathrm{m}^{-2} \mathrm{~d}^{-1}$. Along the transect, water depth varied between 64 and $2478 \mathrm{~m}$ with $83 \%$ of stations located at depths $>200 \mathrm{~m}$ (Fig. 2A). Sea-ice coverage ranged from 0 to $70 \%$, with the highest values at both ends of the transect (Fig. 2B). Water depth, incident irradiance and sea-ice coverage were not significantly different between the 3 provinces (Kruskal-Wallis tests, $\mathrm{p}>0.05$ ). The $Z_{\mathrm{m}}$ was shallow throughout the 3 regions, with depths varying between 4 and $21 \mathrm{~m}$ (Fig. 2C). The $Z_{\text {eu }}$ varied between 30 and $107 \mathrm{~m}$, with significantly higher values in the Beaufort Sea than in the NWP and northern BB (ANOVA, p $<0.0001$; Fig. 2C). The nitracline was always located below the $Z_{\mathrm{m}}$ and above the $Z_{\text {eu }}$ (data not shown). The water column stratification index was significantly higher in the Beaufort Sea and NWP than in northern BB (Kruskal-Wallis test, p $<0.0001$; Fig. 2D).

Surface water temperature ranged from -0.98 to $5.05^{\circ} \mathrm{C}$, with the colder temperatures recorded at stations with sea-ice coverage $\left(<0^{\circ} \mathrm{C}_{i}\right.$ Figs. $\left.2 \mathrm{~B} \& 3 \mathrm{~A}\right)$. Water temperature in intermediate and bottom layers ranged from -1.21 to 3.92 and -1.66 to $2.86^{\circ} \mathrm{C}$, respectively. Salinity ranged from 23.8 to $32.5,24.6$ to 33.3 and 25.4 to 33.4 in surface, intermediate and bottom layers, respectively (Fig. 3B). At the base of the euphotic zone (the bottom layer), salinity was $>31$ at all stations, except at the shallow Stns 6 and 7 in the NWP. In northern $\mathrm{BB}$, salinity showed the least vertical and horizontal variability (Fig. 3B). The euphotic zone was significantly less saline in the Beaufort Sea and NWP than in northern BB (ANOVA, p < 0.01).

Generally, $\mathrm{NO}_{3}$ represented the largest fraction $(64.3 \pm 20.3 \%$, mean $\pm \mathrm{SD})$ of the dissolved inorganic nitrogen (DIN, the sum of $\mathrm{NO}_{3}+\mathrm{NO}_{2}+\mathrm{NH}_{4}$ ) available in the $Z_{\mathrm{eu}}$. DIN concentrations were $<0.8 \mu \mathrm{mol} \mathrm{l^{-1 }}$ in surface and intermediate layers, except at Stn $\mathrm{p}$ (Fig. 3C). In the bottom layer, DIN concentrations ranged from 0.1 to $11.5 \mu \mathrm{mol} \mathrm{l} \mathrm{l}^{-1}$. $\mathrm{Si}(\mathrm{OH})_{4}$ concentra-

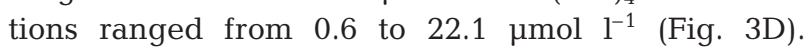
$\mathrm{Si}(\mathrm{OH})_{4}$ concentrations were generally higher in the bottom layer than in the shallower layers. $\mathrm{Si}(\mathrm{OH})_{4}$ concentrations were significantly higher in the NWP 

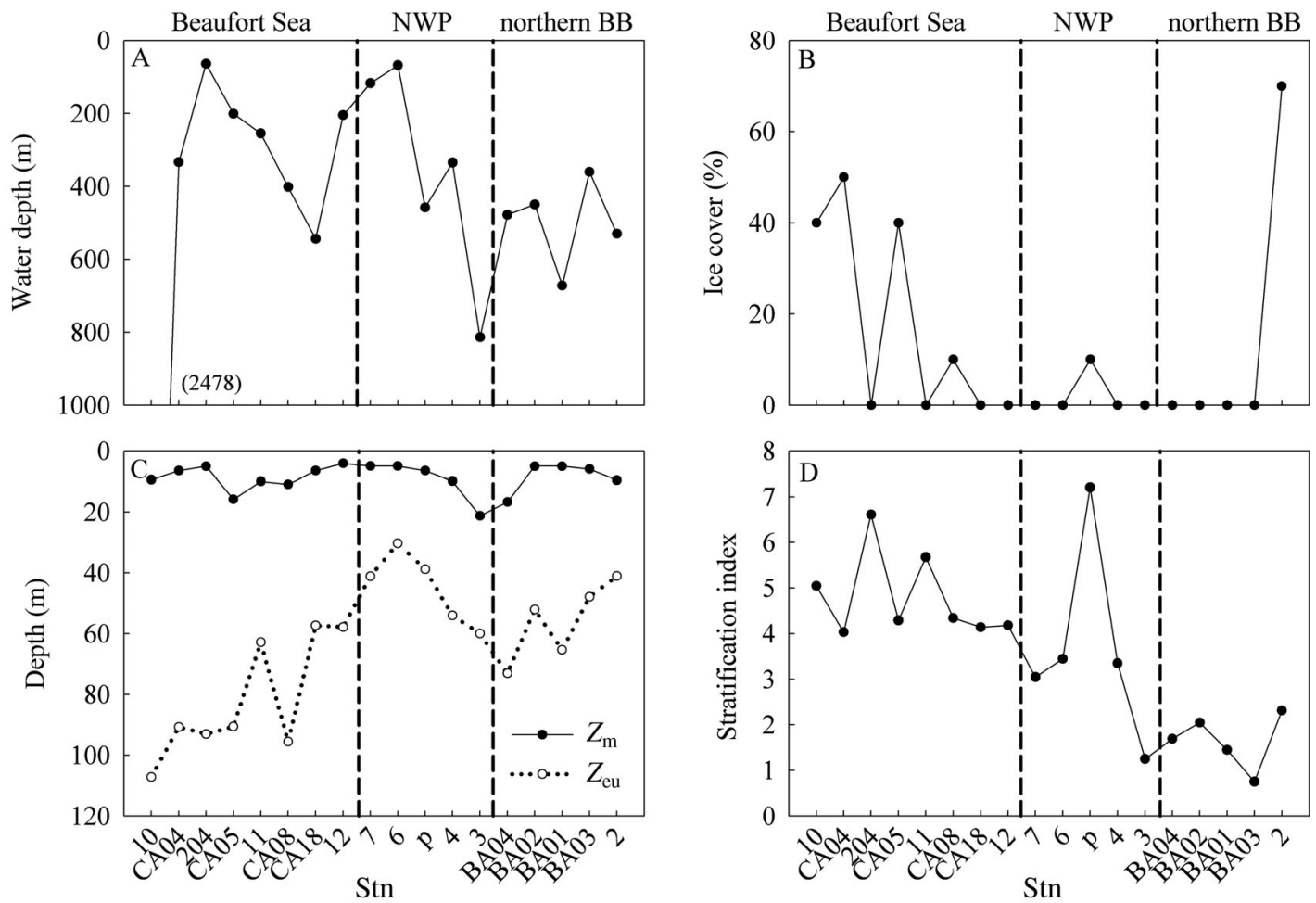

Fig. 2. Variations of the (A) water depth, (B) sea-ice coverage, (C) depths of the euphotic zone $\left(Z_{\text {eu }}\right)$ and the surface mixed layer $\left(Z_{\mathrm{m}}\right)$, and $(\mathrm{D})$ vertical stratification index (the difference in sigma-t between 80 and $5 \mathrm{~m}$ ) along a transect across the Canadian High Arctic. All stations are plotted against longitude, except for stations in northern Baffin Bay (BB), which are plotted against latitude. In (C), $Z_{\text {eu }}$ at Stns $\mathrm{p}$ and 204 were estimated from the values measured at the 2 nearest stations. NWP: Northwest Passage
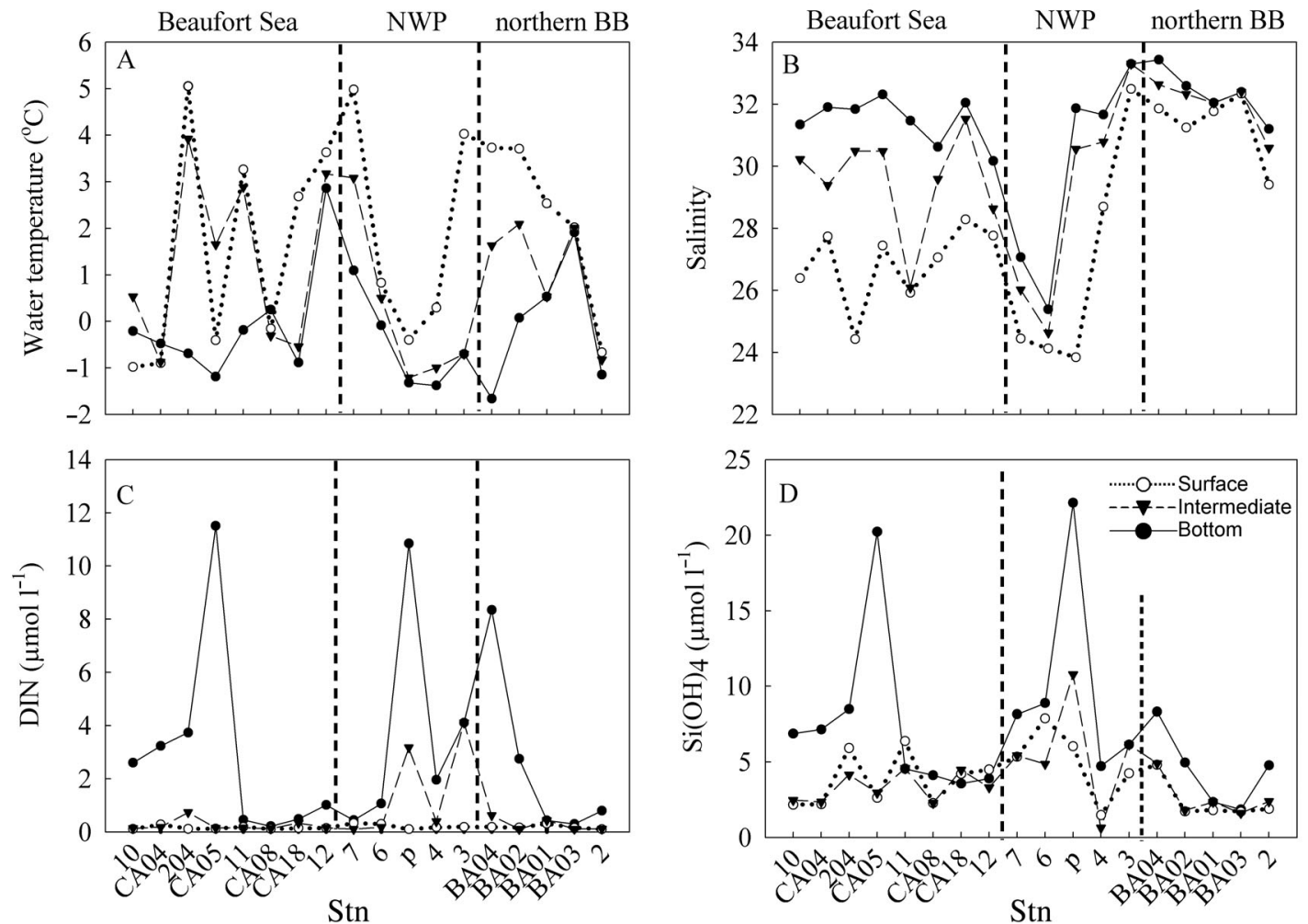

Fig. 3. Variations of (A) water temperature, (B) salinity, (C) dissolved inorganic nitrogen $\left(\mathrm{DIN}=\mathrm{NO}_{3}+\mathrm{NO}_{2}+\mathrm{NH}_{4}\right)$ concentration, and (D) silicic acid $\left(\mathrm{Si}(\mathrm{OH})_{4}\right)$ concentration at 3 sampled depths in the euphotic zone along a transect across the Canadian High Arctic. BB: Baffin Bay; NWP: Northwest Passage 
than in northern BB (ANOVA, $\mathrm{p}<0.05)$. $\mathrm{PO}_{4}$ concentrations ranged from 0.42 to $1.44 \mu \mathrm{mol} \mathrm{l}^{-1}$ throughout the transect (data not shown). The molar ratios of DIN to $\mathrm{Si}(\mathrm{OH})_{4}$ and of DIN to $\mathrm{PO}_{4}$ were $0.14 \pm 0.20$ and $1.06 \pm 1.99$, respectively. These values are significantly lower than Redfield's ratios of 1.1 and 16, respectively (Redfield et al. 1963).

\section{Phytoplankton biomass and abundance}

Total chl a concentrations were highly variable but generally low (i.e. $<0.5 \mu \mathrm{g} \mathrm{l}^{-1}$ in $73 \%$ of samples; Fig. 4A). However, relatively high chl a concentrations
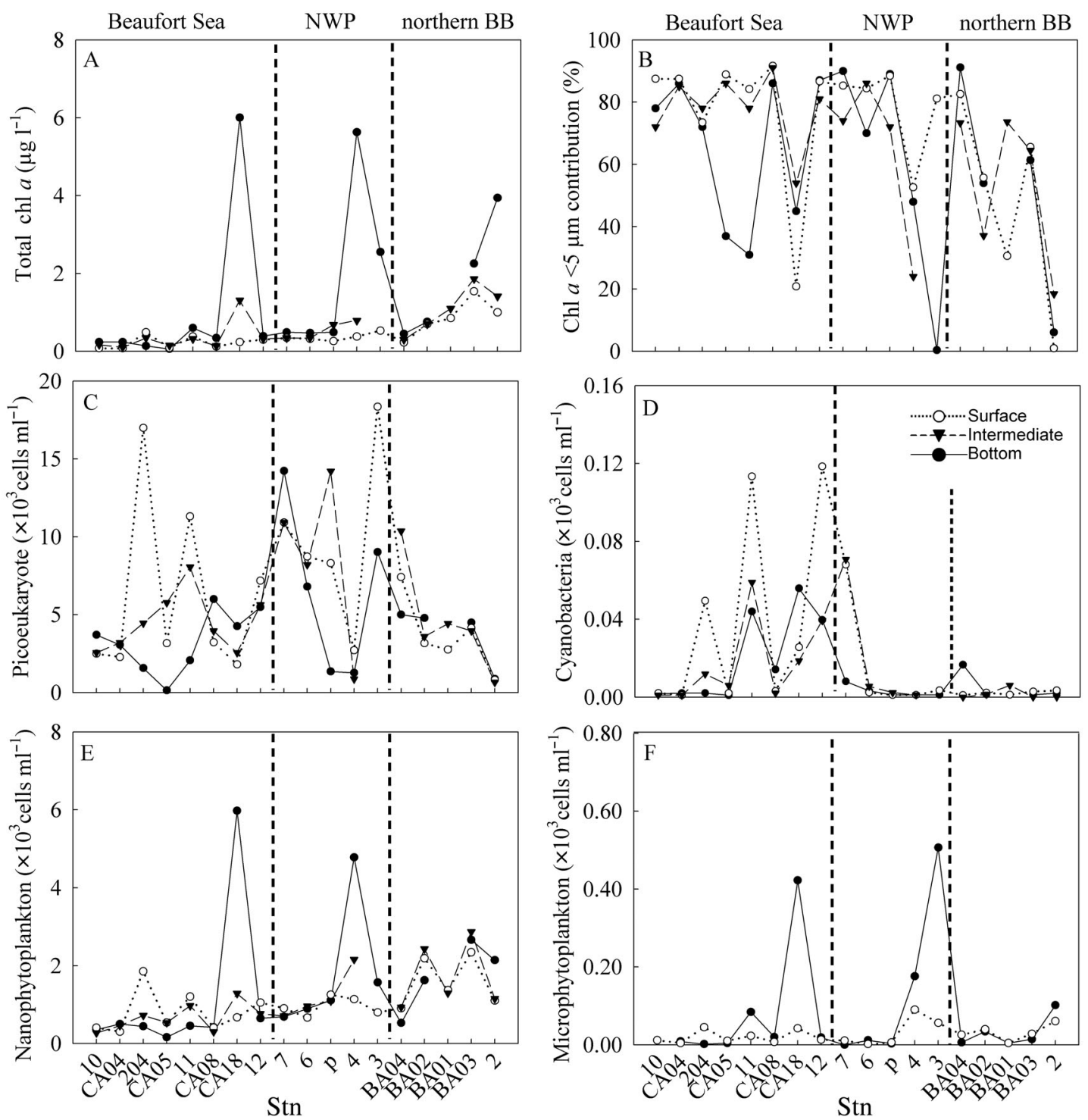

Fig. 4. Variations of (A) total chl a biomass, (B) percentage contribution of small algae $(<5 \mu \mathrm{m})$ to total chl a biomass, (C) picoeukaryote abundance, (D) cyanobacteria abundance, (E) nanophytoplankton abundance, and (F) microphytoplankton abundance at 3 sampled depths in the euphotic zone along a transect across the Canadian High Arctic. In (F), the intermediate depth was not sampled. BB: Baffin Bay; NWP: Northwest Passage $\left(>2 \mu \mathrm{g} \mathrm{l}^{-1}\right)$ were observed in the bottom layer in the Beaufort Sea (Stn CA18), NWP (Stns 4 and 3) and northern BB (Stns BA03 and 2). At half of the 18 stations, $>70 \%$ of the total chl a biomass was represented by cells $<5 \mu \mathrm{m}$ (Fig. 4B).

Small phototrophic eukaryotes were abundant at most of the stations (Fig. 4C). Picoeukaryote abundance varied between 150 and 18400 cells ml $^{-1}$, with the highest abundances observed in the surface waters at Stn 204 in the Beaufort Sea and Stn 3 in the NWP. The lowest picoeukaryote abundances $(<1000$ cells $\mathrm{ml}^{-1}$ ) were measured at Stn CA05 in the Beaufort Sea in the bottom layer, at Stn 4 in the NWP in the intermediate layer and at the northernmost Stn 2 in northern 
BB at all sampling depths. Picocyanobacteria always represented a small percentage $(<2 \%)$ of the picophytoplankton cells, with abundances never exceeding 120 cells $\mathrm{ml}^{-1}$. The highest values were recorded at Stns 11 and 12 in the Beaufort Sea (Fig. 4D). The picophytoplankton abundance was positively correlated with water temperature (Fig. 5), $\mathrm{Si}(\mathrm{OH})_{4}$ concentration and chl $a<5 \mu \mathrm{m}$, and negatively correlated with seaice coverage (Table 2). The percentage contribution of picophytoplankton to total phytoplankton abundance (i.e. pico- + nano- + microphytoplankton) was positively correlated with water temperature $\left(r_{S}=0.37, p<\right.$ 0.01 ) and negatively correlated with total chl a concentration $\left(\mathrm{r}_{\mathrm{S}}=-0.49, \mathrm{p}<0.001\right)$, chl $\mathrm{a}>5 \mu \mathrm{m}\left(\mathrm{r}_{\mathrm{S}}=-0.58\right.$, $\mathrm{p}<0.001)$ and salinity $\left(\mathrm{r}_{\mathrm{S}}=-0.39, \mathrm{p}<0.01\right)$. There was no significant correlation with the other measured variables.

Nanophytoplankton (2 to $20 \mu \mathrm{m}$ ) abundance was an order of magnitude lower than that of picophytoplankton cells, ranging from 160 to 6000 cells $\mathrm{ml}^{-1}$ with abundances generally increasing toward the eastern part of the transect (Fig. 4E). The highest nanophytoplankton abundances were observed at Stn CA18 in the Beaufort Sea and Stn 4 in the NWP in the bottom

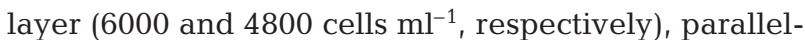
ing the highest chl a concentrations that were also recorded at these stations and depths (Fig. 4A). Nanophytoplankton abundance was significantly lower in the Beaufort Sea than in northern BB (ANOVA, $p<0.05$ ). Microphytoplankton abundance determined by LM was generally $<100$ cells $\mathrm{ml}^{-1}$, except in the bottom layer at Stns CA18, 4 and 3, with

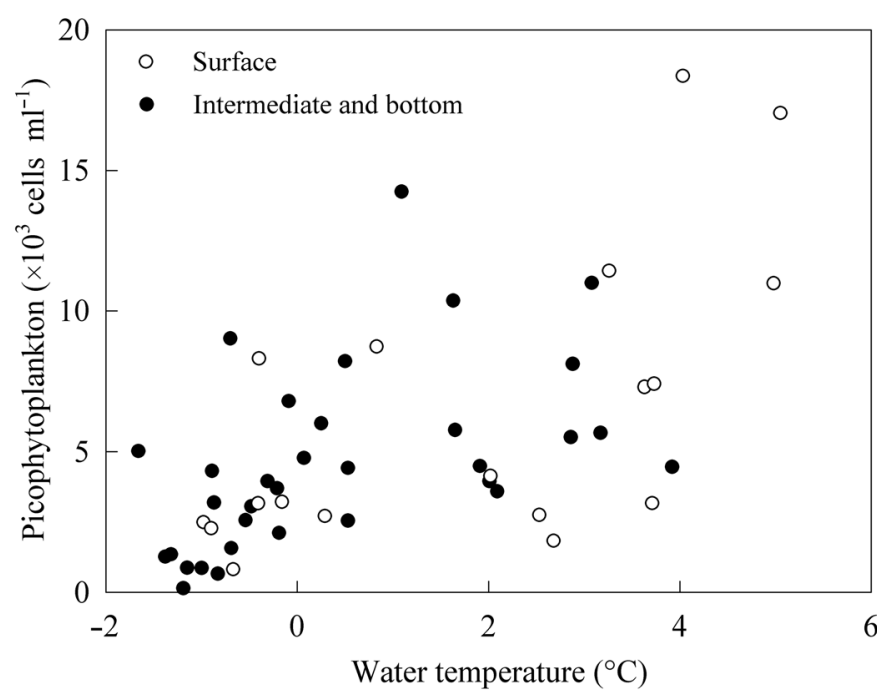

Fig. 5. Relationship between picophytoplankton abundance and water temperature $\left(x_{2}=2.2 x_{1}+3.3, r^{2}=0.35, p<0.001\right)$. Samples were collected from the surface, intermediate and bottom layers of the euphotic zone
Table 2. Spearman correlation coefficients between phytoplankton abundance and environmental and biological factors at all stations and depths. Because of their low abundance, excluding picocyanobacteria and microphytoplankton from these correlations does not affect the significance of the correlation coefficients. ${ }^{*} p<0.05,{ }^{* *} p<0.01,{ }^{* * *} p<0.001$, ns: not significant; DIN: dissolved inorganic nitrogen; $Z_{\mathrm{eu}}$ : euphotic depth; $Z_{\mathrm{m}}$ : surface mixed-layer depth

\begin{tabular}{|lcc|}
\hline & $\begin{array}{c}\text { Phytoplankton } \\
<2 \mu \mathrm{m}\end{array}$ & $\begin{array}{c}\text { Phytoplankton } \\
>2 \mu \mathrm{m}\end{array}$ \\
\hline Temperature & $0.55^{* * *}$ & $\mathrm{~ns}$ \\
Salinity & $\mathrm{ns}$ & $0.29^{*}$ \\
Stratification index & $\mathrm{ns}$ & $-0.46^{* * *}$ \\
Ice coverage & $-0.44^{* *}$ & $-0.46^{* * *}$ \\
$\mathrm{Z}_{\mathrm{m}}$ & $\mathrm{ns}$ & $\mathrm{ns}$ \\
$\mathrm{Z}_{\mathrm{eu}}$ & $\mathrm{ns}$ & $-0.58^{* * *}$ \\
$\mathrm{DIN}$ & $\mathrm{ns}$ & $\mathrm{ns}$ \\
$\mathrm{Si}(\mathrm{OH})_{4}$ & $0.37^{* *}$ & $\mathrm{~ns}$ \\
$\mathrm{PO}{ }_{4}$ & $\mathrm{~ns}$ & $-0.36^{* *}$ \\
Total chl a & $\mathrm{ns}$ & $0.84^{* * *}$ \\
$\mathrm{Chl} a>5 \mu \mathrm{m}$ & $\mathrm{ns}$ & $0.80^{* * *}$ \\
$\mathrm{Chl} a<5 \mu \mathrm{m}$ & $0.35^{*}$ & $0.57^{* * *}$ \\
& & \\
\hline
\end{tabular}

values of 420,175 and 500 cells $\mathrm{ml}^{-1}$, respectively (Fig. 4F). The large phytoplankton ( $>2 \mu \mathrm{m})$ abundance was positively correlated with total chl $a$, chl $a>5 \mu \mathrm{m}$, chl $a<5 \mu \mathrm{m}$ and salinity, and negatively correlated with $Z_{\text {eu }}$ vertical stratification index, sea-ice coverage and phosphate concentration (Table 2). Overall, the contribution of pico-, nano- and microphytoplankton to total phytoplankton abundance was 76.2 $\pm 20.1,23.2 \pm$ 19.6 and $0.6 \pm 1.1 \%$, respectively.

\section{Taxonomic composition and accessory pigments}

There was a strong linear relationship between nanophytoplankton FCM and LM counts, with a slope of 0.67 and $95 \%$ CI ranging from 0.60 to $0.74\left(\mathrm{r}^{2}=0.91\right.$, $\mathrm{p}<0.0001$; Fig. 6). Counts were very similar for abundances of $<1500$ cells $\mathrm{ml}^{-1}$, but for higher abundances, LM counts gave higher estimates of the number of nanophytoplankton cells. This discrepancy may be explained by the strong coloration of the acidic Lugol's solution making it difficult to distinguish autotrophic from heterotrophic cells using LM (Sherr \& Sherr 1993). Hence, FCM (presented hereafter) may give a more realistic abundance estimate of nanophytoplankton than do LM counts.

In the surface layer, flagellates represented $>75 \%$ of the total nanophytoplankton abundance (i.e. flagellates + dinoflagellates + diatoms), except at Stn 4 in the NWP and Stn 2 in northern BB, where diatoms were abundant (Fig. $7 \mathrm{~A}$ ). In the bottom layer, diatoms were predominant $(>50 \%)$ at Stn CA18 in the Beaufort Sea, 


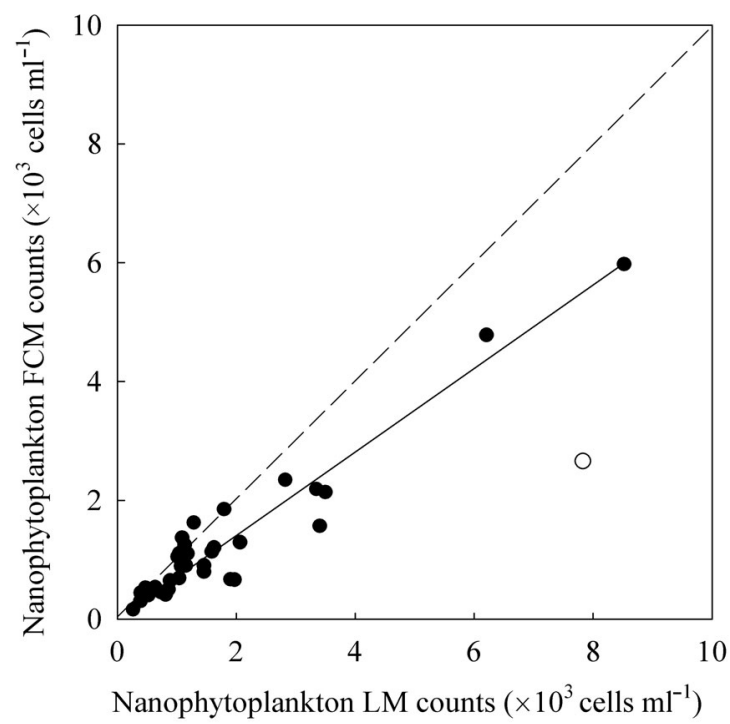

Fig. 6. Relationship between nanophytoplankton abundance estimated by flow cytometry (FCM) and light microscopy (LM) $\left(y=0.7 x+0.09, \mathrm{r}^{2}=0.91, \mathrm{p}<0.0001\right)$. The outlier (O) was excluded from the regression. Dashed line represents a slope of 1

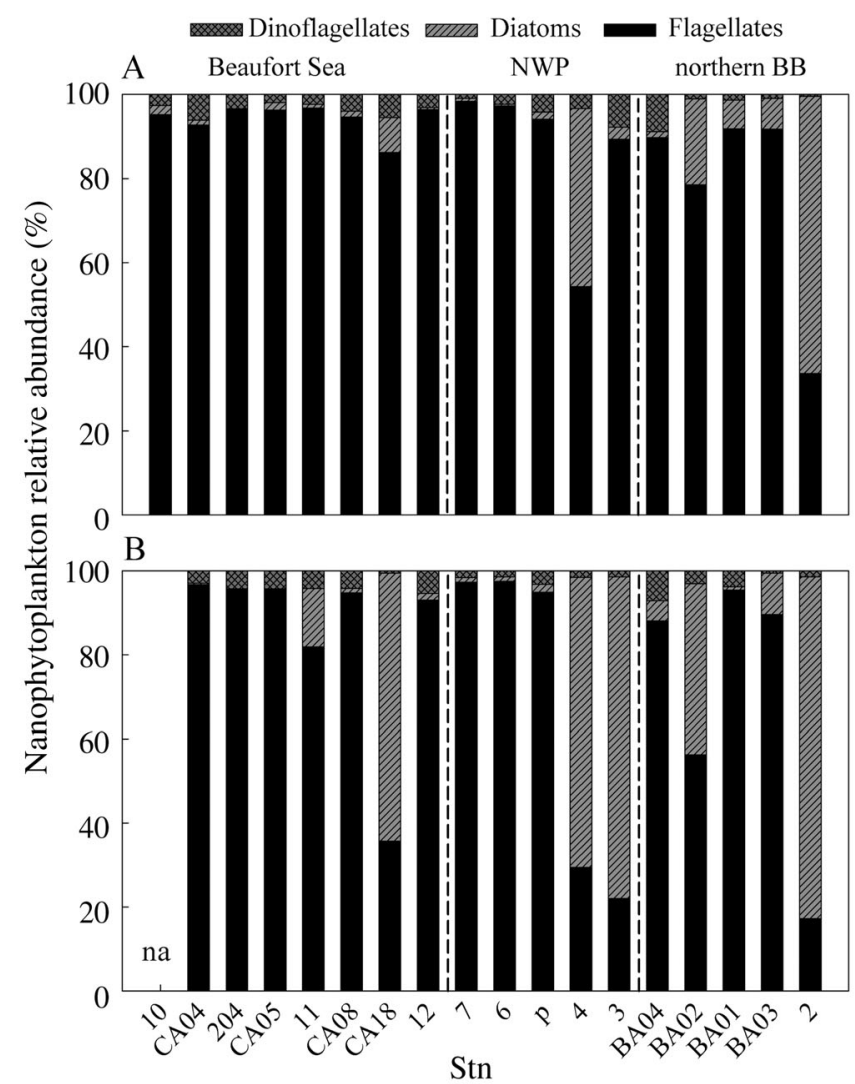

Fig. 7. Variations of the relative abundance of 3 different plankton groups (diatoms, dinoflagellates, flagellates) in (A) the surface layer and (B) the bottom layer of the euphotic zone along a transect across the Canadian High Arctic. na: not available. BB: Baffin Bay; NWP: Northwest Passage
Stns 3 and 4 in the NWP and Stn 2 in northern BB, but flagellates were the most abundant nanophytoplankton at the other stations (Fig. 7B). Surface and bottomlayer nanophytoplankton assemblages were mainly composed of unidentified flagellated cells, centric diatoms of the genus Chaetoceros Ehrenberg (mostly C. socialis Lauder), flagellates belonging to the prymnesiophytes Chrysochromulina Lackey, the prasinophytes Pyramimonas Schmarda and the chrysophyte Dinobryon balticum (Schütt) Lemmermann. The low cell abundance of microphytoplankton prevented a detailed description of the taxonomic composition of that size class; in many samples one or a few cells were observed. Nevertheless, within the $>20 \mu \mathrm{m}$ size fraction, the pennate diatoms Pseudo-nitzschia spp. and Cylindrotheca closterium (Ehrenberg) Reimann et Lewin were the dominant group present across the Canadian Arctic. Some genera belonged, in terms of size, to both nano- and microplankton, such as the dinoflagellate Gyrodinium/Gymnodinium complex, which was present throughout the transect, and the centric diatom Thalassiosira spp., which was present at Stns 2, CA18, 4, 3 and BA01.

The HPLC analysis of chlorophylls and carotenoids from the surface layer along the transect provided additional information for the identification of the algal community (Fig. 8). The pigment distribution showed similarities with the abundance of pico- and nanophytoplankton measured by FCM and the dominant

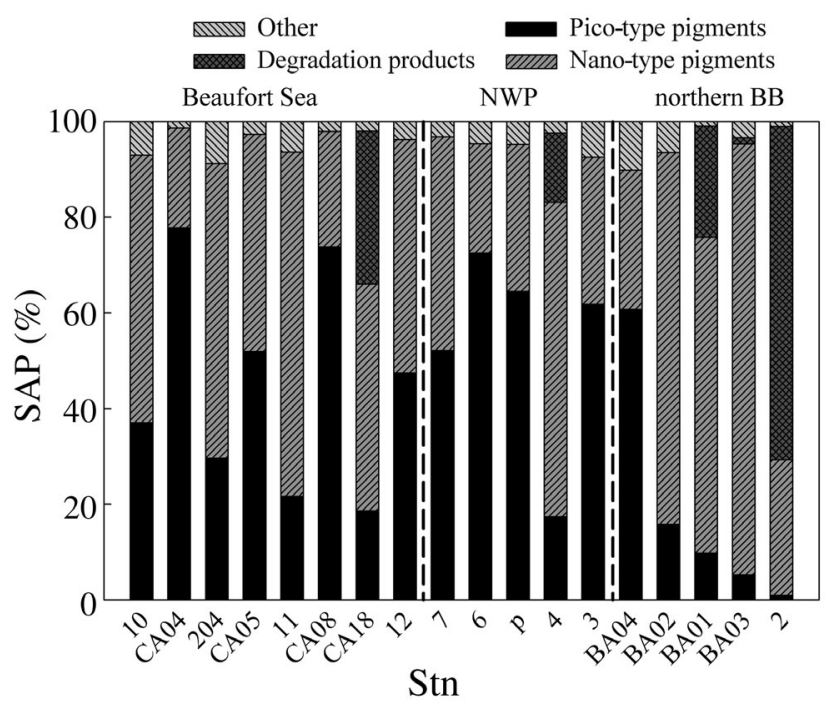

Fig. 8. Percentage contribution of specific accessory pigments (SAP) to total pigments for 4 groups of biomarkers collected in the surface waters. SAP for the pico-type group are: chl $b, \mathrm{Mg}$ DVP, Mmnal, Neo, Lut, Viola, Pras, Uriolide and Zea. SAP for the nano-type group are: Fuco, $\mathrm{chl} c_{2}, c_{1}$, chl $c_{3}$, Hex-fuco, Butfuco, Allo, Diato and Diadino. SAP for the degradation products group are: Chlide $a$, Phide $a$ and Pyro-phide $a$. SAP for the 'Other' group are: Perid and $\beta \beta$-Car. See Table 1 for pigment abbreviations. BB: Baffin Bay; NWP: Northwest Passage 
groups identified by LM. The pigments known to be part of the picophytoplankton size fraction, characterizing prasinophytes and chlorophytes (chl $b, \mathrm{Mg}$ DVP in addition to Mmnal, Neo, Lut, Viola, Pras, Uriolide and Zea; abbreviations explained in Table 1) (Jeffrey et al. 1997), contributed $48.1 \pm 21.6 \%$ of the total pigments identified in the Beaufort Sea and NWP, but only $7.9 \pm 6.3 \%$ in northern BB. Maximum contributions $(>70 \%)$ were observed at Stns CA04, CA08 and 6. Zeaxanthin, which is a major accessory pigment of cyanobacteria and a minor pigment in prasinophytes and chlorophytes, accounted for low concentrations (average $0.003 \mu \mathrm{g} \mathrm{l}^{-1}$, maximum $=0.01 \mu \mathrm{g} \mathrm{l}^{-1}$ at Stn 11) and was detected mostly in the Beaufort Sea and NWP (data not shown).

The pigments known to be found mostly in the nanophytoplankton size fraction (Fuco, chl $C_{2}+C_{1}$, chl $c_{3}$, Hex-fuco, But-fuco, Allo, Diato and Diadino; abbreviations explained in Table 1) were the major pigments detected in northern BB (Stns BA01 to BA03 and 2), and at Stns 10, 204 and 11 in the Beaufort Sea and Stn 4 in the NWP (Fig. 8). Even though fucoxanthin is often associated with microphytoplankton, we included it in the nanophytoplankton size fraction since microphytoplankton represented only $1 \%$ of the total LM count. Furthermore, most diatoms enumerated and identified were in the $<20 \mu \mathrm{m}$ fraction. Stations showing $>15 \%$ of degraded products (Phide $a$, Chlide $a$ and Pyro-Phide $a_{\text {; }}$ see Table 1) had the highest chl $a$ biomass concentration (Stns CA18, 4, BA01 and 2; Figs. 4A \& 8).

In this study, $\beta, \beta$-carotene and peridinin were included in the group labeled other pigments (Fig. 8). They contributed only $4.4 \pm 2.8 \%$ of the pigments identified. $\beta, \beta$-carotene is known to be present in various algal groups, which can be included in the pico-, nano- and microphytoplankton size fraction, and peridinin is a biomarker for dinoflagellates. In the samples examined by LM, dinoflagellates were present in the nano- and microphytoplankton size fraction. Hence, it is difficult to use these 2 pigments as biomarkers for a specific size fraction. As the algal community in the Arctic, at least in late summer, is well represented by pico- and nanophytoplankton, we did not use the method of Uitz et al. (2006) to derive community composition. These authors include the pigment fucoxanthin as a tracer for diatoms, which in their study belong to the microphytoplankton size fraction. As indicated above, most of the diatoms belong to the nanophytoplankton size fraction in the present study.

\section{Dominance of small phytoplankton cells}

The relationship between the percentage contribution of picophytoplankton to total phytoplankton cell abundance (pico- + nano- + microphytoplankton) and their estimated contribution to total chl a biomass is presented in Fig. 9. Calculated picoplankton chl a was responsible for 1 to $96 \%$ of the total chl a along the transect. In the Beaufort Sea, the estimated chl a biomass of cells $<2 \mu \mathrm{m}$ represented $49 \%$ of the total chl a. In the NWP, this proportion was similar, with an average of $47 \%$ and a maximum of $78 \%$ at Stn 7 . In northern $\mathrm{BB}$, this proportion was considerably lower with, on average, an estimated chl a biomass of cells $<2 \mu \mathrm{m}$ representing $20 \%$.

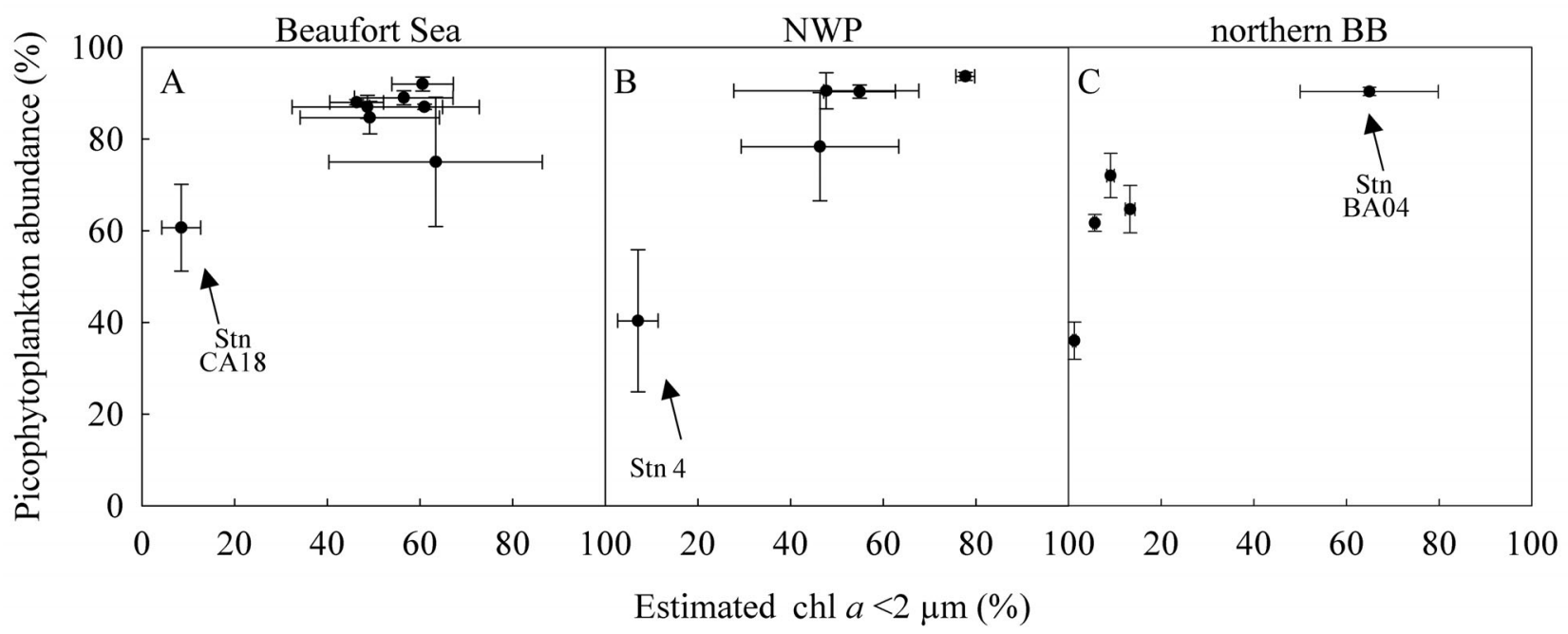

Fig. 9. Relationships between percentage contribution of picophytoplankton to total phytoplankton abundance (pico- + nano- + microphytoplankton) and percentage contribution of calculated picoplankton chl a to total chl a biomass for (A) Beaufort Sea, (B) Northwest Passage (NWP), and (C) northern Baffin Bay (BB). Error bars represent the standard error for the 3 sampled depths in the euphotic zone (i.e. surface, intermediate and bottom) 


\section{DISCUSSION}

\section{Dominance of photosynthetic picoeukaryotes across the Arctic Ocean}

The distribution of pico-, nano- and microphytoplankton was studied along a $3500 \mathrm{~km}$ transect from northern BB to the Beaufort Sea passing through the NWP in late summer of 2005. Picophytoplankton were consistently the most abundant algal cells in the euphotic zone, with maximum values reaching 17000,18400 and 10400 cells ml $^{-1}$ in the Beaufort Sea, NWP and northern BB, respectively (Fig. 4C,D, Table 3). In addition, the vertical distribution of picophytoplankton within the euphotic zone was, in general, more homogeneous in northern BB. In the latter province, the upper water column was less stratified (Fig. 2D). The picophytoplankton assemblage was overwhelmingly dominated by photosynthetic eukaryotes, with picocyanobacteria representing at most $2 \%$ of total picophytoplankton cells. This contrasts with studies conducted in mid- and low-latitude marine systems, where picocyanobacteria can be numerically dominant (Buck et al. 1996), as discussed below.

Recent observations also provided evidence of a high abundance of picoeukaryotes and a scarcity of cyanobacteria in the Arctic Ocean and adjacent seas (Table 3). Not et al. (2005) studied the picophytoplankton distribution at the boundary between the Norwegian, Greenland and Barents seas in late summer. In Arctic waters, they found picoeukaryote abundances reaching 10200 cells ml $^{-1}$ and no occurrence of picocyanobacteria. However, they recorded up to 30000 cells ml ${ }^{-1}$ of the picocyanobacteria Synechococcus in the more saline and warmer Atlantic waters. During the Arctic Ocean Section, Booth \& Horner (1997) recorded similar picoeukaryote abundances in summer and did not observe Synechococcus. In northern BB, Mostajir et al. (2001) found lower picoeukaryote abundances (Table 3), but still without any occurrence of picocyanobacteria in early fall.

Table 3. Abundance of photosynthetic picoeukaryotes and of the picocyanobacteria Synechococcus sp. in the Arctic Ocean and adjacent seas. Sea surface temperature and salinity are shown. FCM: flow cytometry; FISH: fluorescence in situ hybridization; -: not observed

\begin{tabular}{|c|c|c|c|c|c|c|}
\hline Location & Method & $\begin{array}{l}\text { Picoeukaryote } \\
\left(\text { cells ml-1 } \mathrm{m}^{-1}\right)\end{array}$ & $\begin{array}{c}\text { Synechococcus } \\
\left(\text { cells } \mathrm{ml}^{-1} \text { ) }\right.\end{array}$ & $\begin{array}{c}\text { Temperature } \\
\left({ }^{\circ} \mathrm{C}\right)\end{array}$ & Salinity & Source \\
\hline $\begin{array}{l}\text { Chukchi Sea to } \\
\text { Makarov Basin }\end{array}$ & $\begin{array}{l}\text { Epifluorescence } \\
\text { microscopy }\end{array}$ & $1000-10000$ & - & -1.8 to -1.5 & $29-34$ & Booth \& Horner (1997) \\
\hline $\begin{array}{l}\text { Mackenzie Shelf/ } \\
\text { Amundsen Gulf }\end{array}$ & $\begin{array}{l}\text { Epifluorescence } \\
\text { microscopy }\end{array}$ & $215-2110$ & $470-2425$ & -1.3 to 0.1 & $20.3-26.9$ & Waleron et al. $(2007)^{b}$ \\
\hline $\begin{array}{l}\text { Resolute } \\
\text { Passage }\end{array}$ & $\begin{array}{l}\text { Epifluorescence } \\
\text { microscopy }\end{array}$ & $0-5860^{\mathrm{c}}$ & $0-6330$ & -1.79 to -1.73 & $32.7-33.5$ & Robineau et al. (1999) ${ }^{\mathrm{d}}$ \\
\hline $\begin{array}{l}\text { Northeast } \\
\text { Water Polynya }\end{array}$ & $\begin{array}{l}\text { Epifluorescence } \\
\text { microscopy }\end{array}$ & $20-7430^{\mathrm{c}}$ & $0-330$ & -1.73 to 4.23 & $25.1-33.9$ & Robineau et al. (1999) \\
\hline $\begin{array}{l}\text { Northern Baffin } \\
\text { Bay }\end{array}$ & FCM & 661-10365 & $0-17$ & -1.66 to 3.73 & $29.4-33.4$ & Present study ${ }^{\mathrm{f}}$ \\
\hline $\begin{array}{l}\text { Greenland, } \\
\text { Norwegian and } \\
\text { Barents seas } \\
\text { (Arctic waters) }\end{array}$ & $\begin{array}{c}\text { FCM } \\
\text { FISH cell counts }\end{array}$ & $2600-10200$ & - & 4.5 & 34.5 & Not et al. $(2005)^{\mathrm{f}}$ \\
\hline $\begin{array}{l}\text { Greenland, } \\
\text { Norwegian and } \\
\text { Barents seas } \\
\text { (Atlantic waters) }\end{array}$ & $\begin{array}{c}\text { FCM } \\
\text { FISH cell counts }\end{array}$ & $<3000-17000$ & $0-30000$ & 7 & $>34.5$ & Not et al. $(2005)^{\mathrm{f}}$ \\
\hline
\end{tabular}


The analysis of the pigment composition by HPLC allowed us to determine the main classes among picoeukaryote cells. The ubiquity of chl $b+\mathrm{Mg}$ DVP chlorophylls in the Beaufort Sea, NWP and at Stn BA04 in northern $\mathrm{BB}$ indicates the presence of prasinophytes and possibly chlorophytes in the euphotic zone (Jeffrey et al. 1997). In addition, the carotenoids typical of prasinophytes (i.e. Neo, Pras, Mmnal, Lut, Uriolide and Zea; see Table 1) were observed in this study. Therefore, we suggest that a fraction of these pigments belong to the species Micromonas pusilla, which is now thought to be the major component of the photosynthetic picoeukaryote community in Arctic waters (Lovejoy et al. 2007). This prasinophyte was observed in many regions of the Arctic, such as in the central Arctic Ocean (Booth \& Horner 1997), the Chukchi Plateau and the Canada Basin (Sherr et al. 2003), the Norwegian and Barents seas (Not et al. 2005) and northern BB (Lovejoy et al. 2007). This species was formally identified through tyramide signal amplification-fluorescence in situ hybridization and 18S rDNA analyses by Not et al. (2005) and Lovejoy et al. (2007), respectively. In this study, zeaxanthin, the major tracer for cyanobacteria, was in very low concentration, confirming the low abundance of picocyanobacteria compared to picoeukaryotes along the transect. The strong predominance of $M$. pusilla over other picophytoplankton species in Arctic waters is similar to the cyanobacteria dominance observed in tropical and temperate open gyres, where the genera Prochlorococcus Chisholm, Frankel, Goericke, Olson, Palenik, Waterbury, West-Johnsrud et Zettler and Synechococcus are dominant (Partensky et al. 1999).

In the Canadian Arctic, picocyanobacteria were slightly more abundant in the Beaufort Sea and NWP, especially at less saline and shallower stations without sea-ice coverage (Stns 204, 11, CA18, 12 and 7; Fig. 4D). Such low abundance (i.e. 10 to 120 cells ml$^{-1}$ ) is not indicative of an ecologically important role played by these cells. However, their presence is in agreement with other studies that show a higher abundance of cyanobacteria in the plume of rivers and deltas. Along a salinity gradient from the Lena River delta (salinity $<1.3$ ) to the open Laptev Sea (salinity 14.0 to 32.4), Moreira-Turcq \& Martin (1998) showed a decrease in the number of Synechococcus cells (from $>20000$ to 0 cells $\mathrm{ml}^{-1}$ ). More recently, Waleron et al. (2007) described a similar decrease in picocyanobacteria abundance from the Mackenzie River (up to 6713 cells $\mathrm{ml}^{-1}$ ) to offshore sites near the Arctic pack ice (225 to 560 cells ml $^{-1}$ ). From Stn p toward the eastern Canadian Arctic, picocyanobacteria were quasi-absent except at the bottom of the euphotic zone of Stn BA04 (Fig. 4D), where they reached 20 cells $\mathrm{ml}^{-1}$. The occurrence of these cells at the southernmost station of northern BB can be explained by the northward transport of Atlantic water into BB by the West Greenland Current (Ingram et al. 2002). This interpretation is consistent with the observations of Gradinger \& Lenz (1995) and Not et al. (2005) that show the quasiabsence of cyanobacteria in secular waters of the polar mixed layer and higher abundance in Atlantic-influenced waters. Hence, these results support the hypothesis that Atlantic-influenced waters and river inflows favor the growth or transport of picocyanobacteria in Arctic marine systems.

The positive correlation of picophytoplankton abundance with temperatures in the -2 to $5^{\circ} \mathrm{C}$ range (Fig. 5, Table 2) suggests a direct effect of the latter on growth rates. This hypothesis is supported by experimental data obtained with a culture of Micromonas pusilla isolated from northern BB (Lovejoy et al. 2007). The specific growth rates of $M$. pusilla showed a bell-shaped response to temperature, with a maximum of $0.55 \mathrm{~d}^{-1}$ at 6 to $8^{\circ} \mathrm{C}$ and an intermediate value of $0.20 \mathrm{~d}^{-1}$ at 0 and $12^{\circ} \mathrm{C}$. In these experiments, maximum growth was achieved at 50 and $100 \mu \mathrm{mol}$ photons $\mathrm{m}^{-2} \mathrm{~s}^{-1}$ (Lovejoy et al. 2007), which corresponds well to the average irradiance in the euphotic zone (20 to $61 \mu \mathrm{mol}$ photons $\mathrm{m}^{-2} \mathrm{~s}^{-1}$ ) during this study. These comparisons imply that in situ light conditions and the highest temperatures we observed were nearly optimal for the growth of the cold-adapted ecotype of $M$. pusilla found throughout the Arctic Basin (Lovejoy et al. 2007).

\section{Distribution of picophytoplankton versus larger phytoplankton}

Picoeukaryotes were the most abundant algal cells throughout the transect, but they did not dominate the phytoplankton chl a biomass at most stations (Fig. 9). They represented, on average, 82, 77 and $64 \%$ of the total phytoplankton abundance but 49,47 and $20 \%$ of the total phytoplankton chl a biomass in the Beaufort Sea, NWP and northern BB, respectively. Contributions to total chl a biomass, similar to those observed in the western part of the transect, were reported in the Barents and Greenland seas in August-September (mean: 45\%, Not et al. 2005) and in near surface waters in Franklin Bay from November-August (mean: 40 to $80 \%$, Lovejoy et al. 2007). The contribution of picophytoplankton to total phytoplankton carbon biomass was, on average, $36 \%$ in the Canada and Makarov basins in July-August (Booth \& Horner 1997). Hence, picophytoplankton contribution to total phytoplankton biomass in Arctic waters is similar to the average contribution found at lower latitudes (i.e. 40 to $50 \%$ of the total chl a biomass, Agawin et al. 2000). It should be noted, however, that due to their 
fast turnover (Agawin et al. 2000), picophytoplankton cells might make a larger contribution to the community primary production than suggested by their biomass.

In late summer, nanophytoplankton biomass dominated over microphytoplankton in northern BB. Similarly, Sherr et al. (2003) reported that nanophytoplankton dominated the carbon biomass over microphytoplankton in winter (November-May, 57.5\%) and summer (June-September, 83.8\%) in the Canada Basin/Chukchi Plateau and the Chukchi Plateau/ Mendeleyev Basin, respectively. In contrast, Lovejoy et al. (2002) reported that microphytoplankton dominated the total phytoplankton carbon biomass (72 to $98 \%$ ) in the North Water polynya (northern BB) from spring to early summer (April-July). Hence, persistent blooms (Lovejoy et al. 2002), or more occasional blooms, as observed in this study (Fig. 4A,E,F), can be dominated by nano- or microphytoplankton biomass in Arctic waters.

Throughout the transect, flagellates $(<10 \mu \mathrm{m})$ numerically dominated the surface nanophytoplankton community, except at the northernmost Stn 2 of northern BB, where the centric diatom Chaetoceros spp. (diameter 12 to $16 \mu \mathrm{m})$ and C. socialis $(16 \mu \mathrm{m})$, which formed blooms in cold waters (Rat'kova \& Wassmann 2002), dominated the assemblage (Fig. 7A). In the bottom layer of the euphotic zone, Chaetoceros spp. (12 to $16 \mu \mathrm{m})$, Cylindrotheca closterium (>20 $\mu \mathrm{m})$, Pseudo-nitzschia spp. $(2 \times 40 \mu \mathrm{m})$ and Thalassiosira spp. (often $>20 \mu \mathrm{m}$ ) were associated with peaks in chl a concentration and cell abundance observed along the transect (Figs. 4A,E,F \& 7). At most of these stations (Stns CA18, 4, BA01 and 2), post-bloom conditions were encountered as indicated by the high concentrations of chlorophyll degradation products (i.e. Pyrophide $a$, Phide $a$ and Chlide $a$; Fig. 8, Table 1). The pigment signatures suggest that the decline of the bloom was associated to diatom senescence at Stn 4 and grazing at Stns CA18, BA01 and 2. Stn 2 was also characterized by the highest abundance of empty frustules of Chaetoceros, especially C. socialis. This confirms that a late summer bloom of $C$. socialis occurred in northern BB, as shown by Booth et al. (2002).

Nanophytoplankton were more abundant in less stratified waters of northern $\mathrm{BB}$ than in the 2 other provinces (Figs. 2D, 3C \& 4E). Since the polar surface mixed layer is nitrate poor in the western Arctic (Wang et al. 2006) and especially in the southeast Beaufort Sea (Tremblay et al. 2008, the present study), our results support the hypothesis that vertical mixing through its effect on upward nutrient flux to the upper euphotic zone governs the horizontal distribution of large phytoplankton ( $>2 \mu \mathrm{m}$, mainly diatoms) across the Canadian High Arctic in late summer. The enhancement of the nutrient supply by vertical mixing possibly gave a competitive advantage to nanophytoplankton cells over smaller cells in northern BB.

\section{Ecological implications in a changing climate}

A primary incentive for undertaking this study was to describe the phytoplankton distribution in the Canadian High Arctic in late summer when sea-ice coverage and surface water temperature are at their minimum and maximum yearly values, respectively. High-latitude marine ecosystems are particularly sensitive to climate change (ACIA 2005) because small temperature differences can have large effects on the extent and thickness of sea ice (Smetacek \& Nicol 2005). Indeed, the Canadian Arctic is already experiencing a reduction of the sea-ice thickness and a decrease in the sea-ice extent (Holland et al. 2006, Comiso et al. 2008). Rising air temperature and the resulting reduced multi-year ice cover will increase the width of the seasonal ice zone (i.e. the zone lying between maximum [winter] and minimum [summer] ice cover that freezes and melts annually) reaching farther north into the Arctic Ocean in late summer (Carmack \& Wassmann 2006, Serreze et al. 2007). Predicting the effects of these changes on water column stratification and the resulting impacts on light availability and nutrient supply for phytoplankton is not straightforward. The upper water column stratification can be enhanced by increased freshwater inputs from melting of sea ice and glaciers, excess net precipitation and increased river discharge (Peterson et al. 2002) or solar heating. These processes would expose the phytoplankton to higher irradiance, although light availability might also decrease because of suspended sediment and colored dissolved organic matter inputs from river runoff. The increased stratification can also decrease the nutrient supply from deeper waters. However, with a reduced sea-ice cover extent, increased winds may also deepen the surface mixed layer (Carmack \& Wassmann 2006), enhancing the nutrient supply but also decreasing light availability for phytoplankton (Behrenfeld et al. 2006, Carmack \& Wassmann 2006). Our results suggest that future changes in the vertical structure of the water column would have more effects on large phytoplankton than on the smaller ones.

Water temperature was the environmental parameter the most strongly correlated to picophytoplankton abundance along the transect, the abundance of picophytoplankton increasing with water temperature within the euphotic zone (Fig. 5). This positive correlation is also found in a compilation of the published picophytoplankton abundance data from the Arctic 


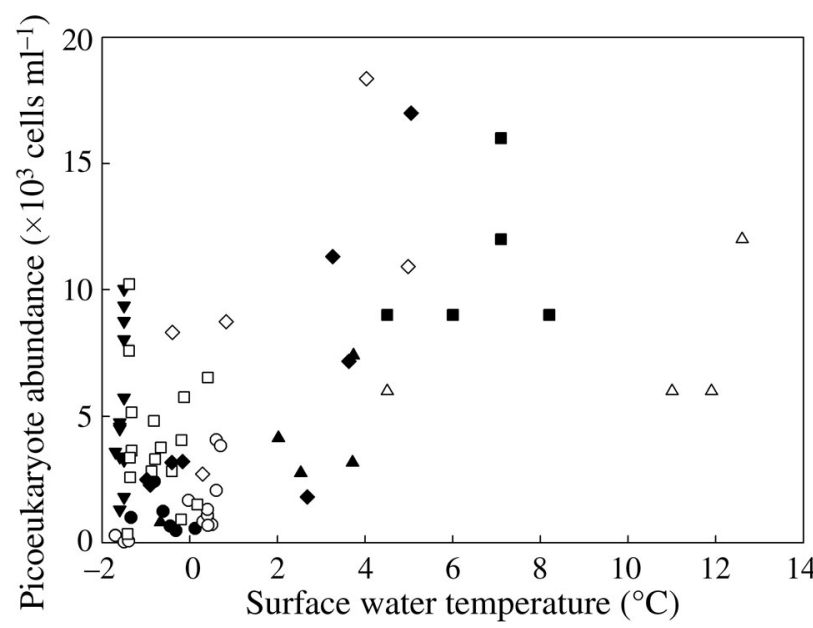

Fig. 10. Relationship between eukaryotic picophytoplankton abundance and surface water temperature from 6 studies conducted in circum-Arctic regions in summer-fall. (•) Beaufort Shelf and Amundsen Gulf (Waleron et al. 2007); (O) Baffin Bay (Mostajir et al. 2001); ( $)$ Canada and Makarov basins (Booth \& Horner 1997); $(\triangle)$ Barents Sea (Not et al. 2005); ( Greenland Sea (Not et al. 2005); ( $\square$ ) Cape Bathurst, ice edge in the Canada Basin and Amundsen Gulf (Schloss et al. 2008); $(\diamond)$ Beaufort Sea (the present study); $(\diamond)$ Northwest Passage (the present study); ( $\mathbf{\Delta})$ northern Baffin Bay (the present study). The 4 open triangles (representing warm Atlantic waters in the Barents Sea from Not et al. 2005) were excluded from the regression $\left(x_{2}=1.7 x_{1}+3.9, r^{2}=0.34, p<0.001\right)$

Ocean (Fig. 10). This would suggest that factors responsible for warmer water temperatures in the Arctic Ocean are also favoring high abundances of picophytoplankton. It is not possible to identify causal relationships from correlations, but the conditions favoring warmer water temperature are likely to be affected by ongoing and predicted climate change. These environmental changes will have consequences throughout the ecosystem, from altering the patterns of primary production to changing the trophic structure and the elemental cycling pathways (Grebmeier et al. 2006).

\section{CONCLUSIONS}

This study was conducted across the Canadian High Arctic during a single, late summer field season. It presented the distribution within the euphotic zone, arguably the most biogeochemically active layer, of all phytoplankton size classes at 18 stations in the seasonal ice zone, the region where most of the Arctic Ocean production takes place (Carmack \& Wassmann 2006). FCM, LM and HPLC pigment analyses showed that the small eukaryote cells $<2 \mu \mathrm{m}$ were the numerically dominant phytoplankton size class and often represented nearly $50 \%$ of the total $\mathrm{chl}$ a biomass in late summer in the Beaufort Sea and NWP. The hypothesis that picocyanobacteria would be more abundant in Atlantic-influenced waters and the vicinity of freshwater input by rivers was validated. In northern BB, nanophytoplankton were significantly more abundant than in the other 2 oceanographic provinces. It is likely that vertical mixing was a key factor regulating the large-scale distribution of phytoplankton through its effect on light availability and nutrient supply from deeper waters. Finally, our results confirm that the picophytoplankton can dominate numerically not only in warm oligotrophic gyres, but also in the cool, nutrient-depleted waters of the Arctic Ocean late in the growth season.

Acknowledgements. This project was supported by grants from ArcticNet (Network of Centres of Excellence of Canada) and the Natural Sciences and Engineering Research Council (NSERC) of Canada to M.G. and M.P., and by financial support from the Canadian Museum of Nature to M.P. Partial operating funds for the CCGS 'Amundsen' were provided by the International Joint Ventures Fund of the Canada Foundation for Innovation and the Fonds québécois de la recherche sur la nature et les technologies (FQRNT). G.T. received a graduate scholarship from the Institut des sciences de la mer de Rimouski (ISMER) and financial support for fieldwork from the Northern Scientific Training Program of the Department of Indian Affairs and Northern Development of Canada. We sincerely thank Chief Scientist A. Rochon, the Canadian Coast Guard officers and the crew of the CCGS 'Amundsen' for their skillful support during the expedition. We sincerely thank Y. Gratton and J. Martin for providing physical and nutrient data, respectively; M.-É. Rail and V. Lago for operating the rosette; M. Simard for technical assistance in the laboratory; and 2 anonymous reviewers for their constructive comments. This is a contribution to the research programs of ArcticNet, ISMER and Québec-Océan.

\section{LITERATURE CITED}

ACIA (2005) Arctic climate impact assessment. Cambridge University Press, Cambridge

Agawin NSR, Duarte CM, Agustí S (2000) Nutrient and temperature control of the contribution of picoplankton to phytoplankton biomass and production. Limnol Oceanogr 45:591-600

Azam F, Fenchel T, Field JG, Gray JS, Meyer-Reil LA, Thingstad F (1983) The ecological role of water-column microbes in the sea. Mar Ecol Prog Ser 10:257-263

Behrenfeld MJ, O'Malley RT, Siegel DA, McClain CR and others (2006) Climate-driven trends in contemporary ocean productivity. Nature 444:752-755

Bell T, Kalff J (2001) The contribution of picophytoplankton in marine and freshwater systems of different trophic status and depth. Limnol Oceanogr 46:1243-1248

Bérard-Therriault L, Poulin M, Bossé L (1999) Guide d'identification du phytoplancton marin de l'estuaire et du golfe $\mathrm{du}$ Saint-Laurent incluant également certains protozoaires. Publ Spéc Can Sci Halieut Aquat 128:1-387

$>$ Booth BC, Horner RA (1997) Microalgae on the Arctic Ocean Section, 1994: species abundance and biomass. Deep-Sea Res II 44:1607-1622

Booth BC, Larouche P, Bélanger S, Klein B, Amiel D, Mei ZP 
(2002) Dynamics of Chaetoceros socialis blooms in the North Water. Deep-Sea Res II 49:5003-5025

Buck KR, Chavez FP, Campbell L (1996) Basin-wide distributions of living carbon components and the inverted trophic pyramid of the central gyre of the North Atlantic Ocean, summer 1993. Aquat Microb Ecol 10:283-298

Carmack E, Wassmann P (2006) Food webs and physicalbiological coupling on pan-Arctic shelves: unifying concepts and comprehensive perspectives. Prog Oceanogr 71:446-477

Comiso JC, Parkinson CL, Gersten R, Stock L (2008) Accelerated decline in the Arctic sea ice cover. Geophys Res Lett 35:L01703, doi:10.1029/2007GL031972

$>$ Cushing DH (1989) A difference in structure between ecosystems in strongly stratified waters and in those that are only weakly stratified. J Plankton Res 11:1-13

DuRand MD, Green RE, Sosik HM, Olson RJ (2002) Diel variations in optical properties of Micromonas pusilla (Prasinophyceae). J Phycol 38:1132-1142

Fortier M, Fortier L, Michel C, Legendre L (2002) Climatic and biological forcing of the vertical flux of biogenic particles under seasonal Arctic sea ice. Mar Ecol Prog Ser 225:1-16

Gosselin M, Levasseur M, Wheeler PA, Horner RA, Booth BC (1997) New measurements of phytoplankton and ice algal production in the Arctic Ocean. Deep-Sea Res II 44: 1623-1644

Gradinger R, Lenz J (1995) Seasonal occurrence of picocyanobacteria in the Greenland Sea and central Arctic Ocean. Polar Biol 15:447-452

Grasshoff K, Kremling K, Ehrhardt M (eds) (1999) Methods of seawater analysis, 3rd edn. Wiley-VCH, New York

Grebmeier JM, Overland JE, Moore SE, Farley EV and others (2006) A major ecosystem shift in the northern Bering Sea. Science 311:1461-1464

Hill V, Cota G, Stockwell D (2005) Spring and summer phytoplankton communities in the Chukchi and Eastern Beaufort Seas. Deep-Sea Res II 52:3369-3385

> Holland MM, Bitz CM, Tremblay B (2006) Future abrupt reductions in the summer Arctic sea ice. Geophys Res Lett 33:L23503, doi:10.1029/2006GL028024

Holmes RM, Aminot A, Kérouel R, Hooker BA, Peterson BJ (1999) A simple and precise method of measuring ammonium in marine and freshwater ecosystems. Can J Fish Aquat Sci 56:1801-1808

Ingram RG, Bâcle J, Barber DG, Gratton Y, Melling H (2002) An overview of physical processes in the North Water. Deep-Sea Res II 49:4893-4906

Jeffrey SW, Mantoura RFC, Wright SW (1997) Phytoplankton pigments in oceanography: guidelines to modern methods. UNESCO, Paris

Legendre L, Le Fèvre J (1991) From individual plankton cells to pelagic marine ecosystems and to global biogeochemical cycles. In: Demers S (ed) Particle analysis in oceanography. Springer-Verlag, Berlin, p 261-300

- Legendre L, Gosselin M, Hirche HJ, Kattner G, Rosenberg G (1993) Environmental control and potential fate of sizefractionated phytoplankton production in the Greenland Sea $\left(75^{\circ} \mathrm{N}\right)$. Mar Ecol Prog Ser 98:297-313

> Lovejoy C, Legendre L, Martineau MJ, Bâcle J, von Quillfeldt $\mathrm{CH}$ (2002) Distribution of phytoplankton and other protists in the North Water. Deep-Sea Res II 49:5027-5047

Lovejoy C, Vincent WF, Bonilla S, Roy S and others (2007) Distribution, phylogeny, and growth of cold-adapted picoprasinophytes in Arctic seas. J Phycol 43:78-89

Lund JWG, Kipling C, Le Cren ED (1958) The inverted microscope method of estimating algal numbers and the statisti- cal basis of estimations by counting. Hydrobiologia 11: 143-170

Marchant HJ, Davidson AT, Wright SW (1987) The distribution and abundance of chroococcoid cyanobacteria in the Southern Ocean. Proc NIPR Symp Polar Biol 1:1-9

Marie D, Simon N, Vaulot D (2005) Phytoplankton cell counting by flow cytometry. In: Andersen RA (ed) Algal culturing techniques. Academic Press, London, p 253-267

Mei ZP, Legendre L, Gratton Y, Tremblay JÉ and others (2002) Physical control of spring-summer phytoplankton dynamics in the North Water, April-July 1998. Deep-Sea Res II 49:4959-4982

> Michaels AF, Silver MW (1988) Primary production, sinking fluxes and the microbial food web. Deep-Sea Res A 35: 473-490

> Michel C, Ingram RG, Harris LR (2006) Variability in oceanographic and ecological processes in the Canadian Arctic Archipelago. Prog Oceanogr 71:379-401

Moreira-Turcq PF, Martin JM (1998) Characterization of fine particles by flow cytometry in estuarine and coastal Arctic waters. J Sea Res 39:217-226

- Mostajir B, Gosselin M, Gratton Y, Booth B and others (2001) Surface water distribution of pico- and nanophytoplankton in relation to two distinctive water masses in the North Water, northern Baffin Bay, during fall. Aquat Microb Ecol 23:205-212

Murphy LS, Haugen EM (1985) The distribution and abundance of phototrophic ultraplankton in the North Atlantic. Limnol Oceanogr 30:47-58

Not F, Massana R, Latasa M, Marie D and others (2005) Late summer community composition and abundance of photosynthetic picoeukaryotes in Norwegian and Barents Seas. Limnol Oceanogr 50:1677-1686

Parsons TR, Maita Y, Lalli CM (1984) A manual of chemical and biological methods for seawater analysis. Pergamon Press, Toronto

Partensky F, Hess WR, Vaulot D (1999) Prochlorococcus, a marine photosynthetic prokaryote of global significance. Microbiol Mol Biol Rev 63:106-127

Peterson BJ, Holmes RM, McClelland JW, Vorosmarty CJ and others (2002) Increasing river discharge to the Arctic Ocean. Science 298:2171-2173

> Rat'kova TN, Wassmann P (2002) Seasonal variation and spatial distribution of phyto- and protozooplankton in the central Barents Sea. J Mar Syst 38:47-75

Redfield AC, Ketchum BH, Richards FA (1963) The influence of organisms on the composition of seawater. In: Hill MN (ed) The sea, Vol 2. John Wiley, New York, p 26-77

Richardson TL, Jackson GA (2007) Small phytoplankton and carbon export from the surface ocean. Science 315: $838-840$

Robineau B, Legendre L, Michel C, Budeus G, Kattner G, Schneider W, Pesant S (1999) Ultraphytoplankton abundances and chlorophyll a concentrations in ice-covered waters of northern seas. J Plankton Res 21:735-755

Schloss IR, Nozais C, Mas S, van Hardenberg B and others (2008) Picophytoplankton and nanophytoplankton abundance and distribution in the southeastern Beaufort Sea (Mackenzie Shelf and Amundsen Gulf) during Fall 2002. J Mar Syst 74:978-993

> Serreze MC, Holland MM, Stroeve J (2007) Perspectives on the Arctic's shrinking sea-ice cover. Science 315:1533-1536

Sherr EB, Sherr BF (1993) Preservation and storage of samples for enumeration of heterotrophic protists. In: Kemp PF, Sherr BF, Sherr EB, Cole JJ (eds) Current methods in aquatic microbial ecology. Lewis Publishers, New York, p 207-212 
Sherr EB, Sherr BF, Wheeler PA, Thompson K (2003) Temporal and spatial variation in stocks of autotrophic and heterotrophic microbes in the upper water column of the central Arctic Ocean. Deep-Sea Res I 50:557-571

Sieburth JMcN, Smetacek V, Lenz J (1978) Pelagic ecosystem structure: heterotrophic compartments of the plankton and their relationship to plankton size fractions. Limnol Oceanogr 23:1256-1263

Smetacek V, Nicol S (2005) Polar ocean ecosystems in a changing world. Nature 437:362-368

Sokal RR, Rohlf FJ (1995) Biometry: the principles and practice of statistics in biological research, 3rd edn. WH Freeman, New York

Thomson RE, Fine IV (2003) Estimating mixed layer depth from oceanic profile data. J Atmos Ocean Technol 20: $319-329$

Tomas CR (ed) (1997) Identifying marine phytoplankton. Academic Press, San Diego, CA

Tremblay JÉ, Legendre L, Therriault JC (1997) Size-differential effects of vertical stability on the biomass and production of phytoplankton in a large estuarine system. Estuar Coast Shelf Sci 45:415-431

Tremblay JÉ, Simpson K, Martin J, Miller L, Gratton Y, Barber D, Price NM (2008) Vertical stability and the annual dynamics of nutrients and chlorophyll fluorescence in the coastal,

Editorial responsibility: Robert Sanders,

Philadelphia, Pennsylvania, USA southeast Beaufort Sea. J Geophys Res 113:C07S90, doi: 10.1029/2007JC004547

Uitz J, Claustre H, Morel A, Hooker SB (2006) Vertical distribution of phytoplankton communities in open ocean: an assessment based on surface chlorophyll. J Geophys Res 111:C08005, doi: 10.1029/2005JC003207

Vincent WF (2000) Cyanobacterial dominance in the polar regions. In: Whitton $\mathrm{BA}$, Potts $\mathrm{M}$ (eds) The ecology of cyanobacteria: their diversity in time and space. Kluwer Academic Publishers, Dordrecht, p 321-340

- Waleron M, Waleron K, Vincent WF, Wilmotte A (2007) Allochthonous inputs of riverine picocyanobacteria to coastal waters in the Arctic Ocean. FEMS Microbiol Ecol 59:356-365

Wang D, Henrichs SM, Guo L (2006) Distributions of nutrients, dissolved organic carbon and carbohydrates in the western Arctic Ocean. Cont Shelf Res 26:1654-1667

> Wassmann P, Reigstad M, Haug T, Rudels B and others (2006) Food webs and carbon flux in the Barents Sea. Prog Oceanogr 71:232-287

Zapata M, Rodríguez F, Garrido JL (2000) Separation of chlorophylls and carotenoids from marine phytoplankton: a new HPLC method using a reversed phase $\mathrm{C}_{8}$ column and pyridine-containing mobile phases. Mar Ecol Prog Ser 195:29-45

Submitted: May 26, 2008; Accepted: October 12, 2008 Proofs received from author(s): January 20, 2009 